\title{
Local Health Departments
}

\section{GROWTH or ILLUSION?}

BARKEV S. SANDERS, Ph.D.

$\mathrm{S}$ TUDENTS of public health as well as civic leaders have begun to scrutinize the efficacy of the traditional pattern of local health departments (1-3). A critical look at the growth of these departments in recent years is therefore timely.

The growth of local health departments may be measured in several ways, each way possibly leading to a different conclusion. When independent approaches lead to common conclusions, however, we are justified in having greater confidence in the findings. We have chosen three methods of measuring the growth of local health departments in recent years :

- Extent of geographic areas covered by local health departments.

- Annual expenditures of local health departments.

- Number and skills of full-time local public health personnel.

\section{Geographic Coverage}

A few large cities in Europe and in the United States had developed municipal health departments even before the 19th century, but the

Dr. Sanders is technical consultant, Program Development Branch, Division of General Health Services, Public Health Service. The article is based on a speech given at the annual conference of the Nebraska State Public Health Association in Lincoln, September 23, 1957. Basic data on the areas, expenditures, and personnel were compiled under the direction of Clifford H. Greve, State Grants Branch, Division of General Health Services. countywide local health department in this country is exclusively the product of the 20th century. According to Williams (4): "There are conflicting claims as to where the first full-time county health department was established. The records indicate that Jefferson County, in which the City of Louisville, Kentucky, is situated, established a full-time health department in 1908. In Guilford, North Carolina, a full-time county health department was established in 1911."

In 1915 there were 15 full-time county health departments; by 1930 this number had risen to $534(5)$. Since these early beginnings, both the number of separate health units and the number of counties with such health units have vastly increased.

The period of greatest growth of full-time local health organizations was between the years 1915 and 1940 (table 1). Since 1950 there have been relatively few additions. The yearly number of counties with organized health departments and the percentage of population included in areas with such departments underscore this conclusion.

Although the rate of expansion in area and in population covered since 1950 has been negligible, this need not mean that local health departments have not grown in other respects: in quality and in scope of services. We, therefore, should look at other indexes of growth.

\section{Annual Expenditures}

From 1947 to 1956, expenditures through local health departments rose almost constantly. Al- 
though there was some slackening in the rate of increase, the year-to-year changes in total expenditures were generally upward (table 2 ).

From 1950 to 1956 total expenditures increased 47 percent, averaging about 8 percent per year. Local funds, which constituted twothirds of the total, increased 52 percent, closely paralleling the increase in total expenditures. Although fewer dollars are involved, the percentage rise in State funds expended by local health departments (72 percent, or about 12 percent a year) was significantly greater than either the total or local increases.

Within this same period, there was a marked decline (31 percent) in the Federal portion. In 1947 Federal funds represented 19 percent of all local public health expenditures; by 1956 this percentage had dropped to 5 .

The casual observer, noting the rise in dollar amounts spent for health programs, may assume that community health needs are being taken care of more adequately today, at least in the areas served by full-time health departments. This presumption is subject to question, however, since the increases occurred in a period of rising costs, when the purchasing power of the dollar was steadily declining.

\section{Equating the Value of the Dollar}

Ordinarily, the economist uses the Consumer Price Index of the Bureau of Labor Statistics in order to convert current dollars into uniform dollars. For most purposes this provides a reasonably adequate adjustment.

The Consumer Price Index uses as its base the prices paid for consumer goods and services purchased by wage earners' families in the period 1947-49. Appraisal of the significance of increases in dollar amounts should also include an adjustment for the population increase in counties served by local health departments in terms of an index reflecting this increase.

The expenditure figures in table 3 were ob-

Table 1. Comparison of coverage of the United States by full-time local health departments for selected years ${ }^{1}$

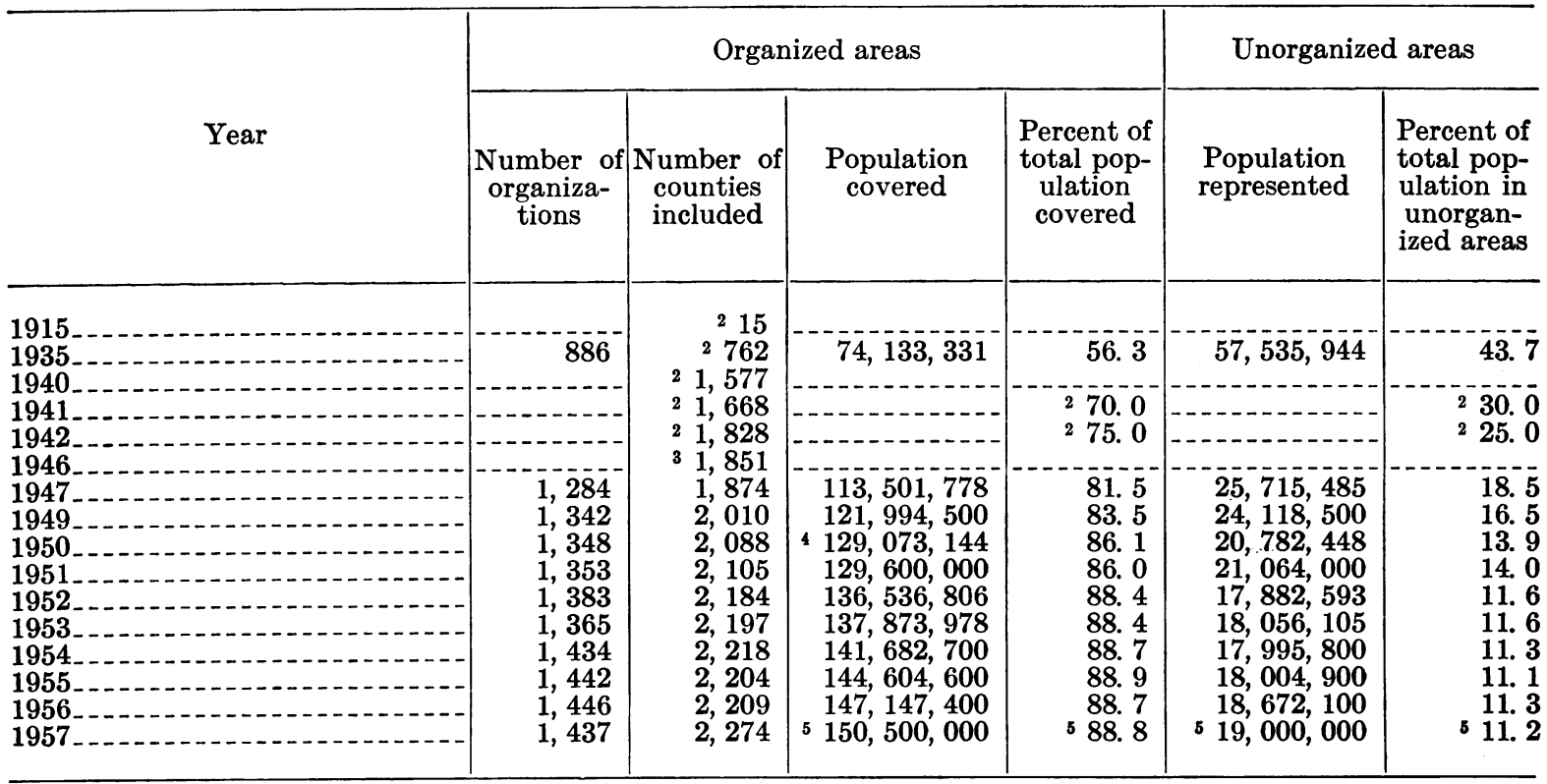

1 Data from the State Grants Branch, Division of General Health Services, Public Health Service, including all State health districts, with additions for early years by the author.

${ }_{2} \mathrm{Kratz}, \mathrm{F}$. W., Status of Full-time Local Health Organization at the End of the Fiscal Year, 1941-42, Pub. Health Rep. 58: 345-351, Feb. 26, 1943.

${ }_{3}$ Mountin, J. W., Hankla, E. K., and Druzina, G. B., Ten Years of Federal Grants-In-Aid for Public Health, 1936-46, Public Health Bulletin No. 300, Public Health Service, 1951.

4 The difference between 1949 and 1950 is due partly to adjustments made possible by current population figures for 1950 provided by the 1950 census.

5 Estimated. 
Table 2. Annual expenditures by local health departments, by source of funds, 1947-56

\begin{tabular}{|c|c|c|c|c|c|}
\hline Fiscal year & $\begin{array}{l}\text { Total expend- } \\
\text { itures }\end{array}$ & Local & State & Federal & $\begin{array}{l}\text { Private } \\
\text { agencies }\end{array}$ \\
\hline $\begin{array}{l}1947 \\
1948 \\
1949 \\
1950 \\
1951\end{array}$ & $\begin{array}{r}\$ 79,876,248 \\
94,961,827 \\
119,072,580 \\
120,353,884 \\
149,773,696 \\
140,781,739 \\
144,317,326 \\
156,428,593 \\
166,130,010 \\
177,427,328\end{array}$ & $\begin{array}{r}\$ 53,754,050 \\
60,721,017 \\
75,187,589 \\
83,274,189 \\
104,254,064 \\
96,766,232 \\
97,370,388 \\
107,995,360 \\
117,988,156 \\
127,163,949\end{array}$ & $\begin{array}{r}\$ 10,270,597 \\
18,983,560 \\
27,167,203 \\
23,337,890 \\
30,871,575 \\
30,275,193 \\
33,620,667 \\
37,742,355 \\
38,100,197 \\
40,232,633\end{array}$ & $\begin{array}{r}\$ 15,180,501 \\
14,533,657 \\
15,510,442 \\
13,131,921 \\
13,644,760 \\
13,131,255 \\
12,500,517 \\
9,614,786 \\
8,916,907 \\
\mathbf{9}, 046,488\end{array}$ & $\begin{array}{r}\$ 671,100 \\
723,593 \\
1,207,346 \\
609,884 \\
1,003,297 \\
609,059 \\
825,754 \\
1,076,092 \\
1,124,750 \\
984,258\end{array}$ \\
\hline
\end{tabular}

1 Three-fourths of increase between 1950 and 1951 attributed to four States: New York, Michigan, Ohio, and Pennsylvania. Increased expenditure was sizable in some of the large cities in the first three States, and more complete reporting of expenditures was noted for Pennsylvania. Some increase was shown, however, for most States.

${ }^{2}$ Although increases between 1951 and 1952 were reported by many States, sizable reduction in funds expended was reported for Detroit and for New York City. The decrease in Detroit resulted from the elimination of general hospitalization cost. Apparently, reported expenditures were incomplete for New York City for 1952.

3 Federal poliomyelitis funds eliminated for reasons of comparability.

Source: As reported to the Public Health Service by State health departments and other State agencies participating in grant programs administered by the Public Health Service. Prepared by the State Grants Branch, Division of General Health Services, Public Health Service.

tained by applying these two indexes to the actual expenditures given in table 2. The top part of table 3 shows what the annual amounts would be after having been deflated by the Consumer Price Index; the lower part, the amounts after further adjustments to allow for population increases.

Both sets of figures are smaller, of course, than those based on current dollars in table 2. The total, deflated by applying the Consumer Price Index only, shows a 30 percent increase instead of the 47 percent increase in table 2 . In terms of deflated dollars the increase in local funds was 35 percent instead of 52 percent and in State funds 52 percent instead of 72 percent. Expenditures of Federal funds by local health departments declined 39 percent in deflated dollars compared with 31 percent in terms of current dollars.

As would be expected, adjustments for population increases reduce the expenditure figures even more. The deflated dollars in table 3 show increases of 14 percent for total expenditures, 19 percent for expenditures of local funds, and 34 percent for expenditures of State funds, and a decrease of 47 percent in expenditures of Federal money.

Although deflation by the Consumer Price Index reduces the slope of the increase in expenditures, the slope still shows some increase.
The question arises whether this index adequately equates the purchasing power of dollars spent for public health. The Consumer Price Index will reduce dollars expended to a common base only if the items purchased are the same commodities and in the same proportions on which the index was based or are closely correlated with these. We know that few local health department dollars are spent for food, clothing, and housing, items which constitute almost three-fourths of all expenditures in the Consumer Price Index. It follows therefore that the use of this index to equate the purchasing power of local health department dollars may not be appropriate. In spite of the deflated amounts obtained by the application of the index, we may still be comparing dollars of unequal purchasing power in different years for the kind of things that were purchased by local health departments.

\section{Deflating Expenditures by Wage Index}

The bulk of local health department expenditures is for personnel. Emerson found that in 1942 the total expenditures of local health departments were $\$ 77.3$ million, of which $\$ 62.7$ million, or 81 percent, was spent for salaries (6). There is no ready-made index as to what adjustments should be made in dollar values 
Table 3. Annual expenditures by local health departments by source of funds, deflated by the Consumer Price Index ${ }^{1}$ and by the population index, ${ }^{2}$ 1950-56

\begin{tabular}{|c|c|c|c|c|c|}
\hline \multirow{2}{*}{ Year } & \multicolumn{5}{|c|}{ Source of funds (in millions of dollars) } \\
\hline & $\begin{array}{c}\text { Total } \\
\text { expendi- } \\
\text { tures }\end{array}$ & Local & State & Federal & $\begin{array}{l}\text { Pri- } \\
\text { vate }\end{array}$ \\
\hline \multirow[b]{2}{*}{$\begin{array}{l}1950 \\
19511^{3} \\
1952 \\
1953 \\
1954 \\
1955 \\
1956\end{array}$} & \multicolumn{5}{|c|}{ Deflated by the consumer price index only } \\
\hline & $\begin{array}{r}\$ 117.1 \\
134.9 \\
124.0 \\
126.1 \\
136.3 \\
145.1 \\
152.7\end{array}$ & $\begin{array}{r}\$ 81.0 \\
93.9 \\
85.2 \\
85.1 \\
94.1 \\
103.0 \\
109.4\end{array}$ & $\begin{array}{r}\$ 22.7 \\
27.8 \\
26.7 \\
29.4 \\
32.9 \\
33.3 \\
34.6\end{array}$ & $\begin{array}{r}\$ 12.8 \\
12.3 \\
11.6 \\
10.9 \\
8.4 \\
7.8 \\
7.8\end{array}$ & $\begin{array}{r}\$ 0.6 \\
.9 \\
.5 \\
.7 \\
.9 \\
1.0 \\
.9\end{array}$ \\
\hline & \multicolumn{5}{|c|}{$\begin{array}{c}\text { Deflated by the consumer price index and } \\
\text { by the population index }\end{array}$} \\
\hline $\begin{array}{l}1950 \\
19513 \\
1952 \\
1953 \\
1954 \\
1955 \\
1956\end{array}$ & $\begin{array}{r}\$ 117.1 \\
134.9 \\
117.0 \\
117.9 \\
123.9 \\
129.6 \\
133.9\end{array}$ & $\begin{array}{r}\$ 81.0 \\
93.9 \\
80.4 \\
79.5 \\
85.6 \\
92.0 \\
96.0\end{array}$ & $\begin{array}{r}\$ 22.7 \\
27.8 \\
25.2 \\
27.5 \\
29.9 \\
29.7 \\
30.4\end{array}$ & $\begin{array}{r}\$ 12.8 \\
12.3 \\
10.9 \\
10.2 \\
7.6 \\
7.0 \\
6.8\end{array}$ & $\begin{array}{r}\$ 0.6 \\
.9 \\
.5 \\
.7 \\
.8 \\
.9 \\
.8\end{array}$ \\
\hline
\end{tabular}

1 Prices paid for consumer goods and services purchased by wage earners' families in the period 1947-49 equals 100.0 .

2 Population in counties with full-time health departments using 1950 as the base (100.0).

3 See table 2, footnotes 1 and 2.

Source: Population covered taken from table 1. Consumer price index data taken from Consumer Price Index, U. S. Bureau of Labor Statistics, table 1, p. 2, July 1956; table 1, p. 2, July 1957.

to give uniform purchasing power for the types of expenditures for which local health department dollars are used. Since well over 80 percent of these expenditures are for wages and salaries of employees, an index based on wages of public health workers for the different years would largely meet the need. However, up-todate information for such an index is not readily available. The latest publication giving information of this type was for $1953(7)$. A more readily available measure-more conservative and yet not too far removed from the appropriate index-would be one based on the annual earnings of full-time equivalent workers (8). The index derived, with 1947-49 as the base, is as follows: $110,118,125,131,134$, 140 , and 147, for the years 1950 through 1956 , respectively.

Table 4 first shows local health department expenditures equated in terms of wages paid in different years to equivalent full-time workers. The figures in the lower half of the table result from an additional adjustment for population increases in counties with full-time health departments.

Total expenditures by local health departments have increased very little in terms of uniform wage dollars. The highest expenditure was for 1951, primarily due, as indicated by

Table 4. Annual expenditures by local health departments by source of funds, deflated by a wage and salary index ${ }^{1}$ and by the population index, ${ }^{2}$ 1950-56

\begin{tabular}{|c|c|c|c|c|c|}
\hline \multirow{2}{*}{ Year } & \multicolumn{5}{|c|}{ Source of funds (in millions of dollars) } \\
\hline & $\begin{array}{c}\text { Total } \\
\text { expendi- } \\
\text { tures }\end{array}$ & Local & State & Federal & $\begin{array}{l}\text { Pri- } \\
\text { vate }\end{array}$ \\
\hline \multirow[b]{2}{*}{$\begin{array}{l}1950 \\
1951^{3} \\
1952 \\
1953 \\
1954 \\
1955 \\
1956\end{array}$} & \multicolumn{5}{|c|}{ Deflated by a wage and salary index only } \\
\hline & $\begin{array}{r}\$ 109.4 \\
126.9 \\
112.6 \\
110.2 \\
117.6 \\
118.7 \\
120.7\end{array}$ & $\begin{array}{r}\$ 75.7 \\
88.3 \\
77.4 \\
74.3 \\
81.2 \\
84.3 \\
86.5\end{array}$ & $\begin{array}{r}\$ 21.2 \\
26.2 \\
24.2 \\
25.7 \\
28.4 \\
27.2 \\
27.4\end{array}$ & $\begin{array}{r}\$ 11.9 \\
11.6 \\
10.5 \\
9.5 \\
7.2 \\
6.4 \\
6.2\end{array}$ & $\begin{array}{r}\$ 0.6 \\
.8 \\
.5 \\
.6 \\
.8 \\
.8 \\
.7\end{array}$ \\
\hline & \multicolumn{5}{|c|}{$\begin{array}{c}\text { Deflated by a wage and salary index and by } \\
\text { the population index }\end{array}$} \\
\hline $\begin{array}{l}1950 \\
1951^{3} \\
19522^{3} \\
1953 \\
1954 \\
1955 \\
1956\end{array}$ & $\begin{array}{r}\$ 109.4 \\
126.9 \\
106.2 \\
103.0 \\
106.9 \\
106.0 \\
105.9\end{array}$ & $\begin{array}{r}\$ 75.7 \\
88.3 \\
73.0 \\
69.4 \\
73.8 \\
75.3 \\
75.9\end{array}$ & $\begin{array}{r}\$ 21.2 \\
26.2 \\
22.8 \\
24.0 \\
25.8 \\
24.3 \\
24.0\end{array}$ & $\begin{array}{r}\$ 11.9 \\
11.6 \\
9.9 \\
8.9 \\
6.5 \\
5.7 \\
5.4\end{array}$ & $\begin{array}{r}\$ 0.6 \\
.8 \\
.5 \\
.6 \\
.7 \\
.7 \\
.6\end{array}$ \\
\hline
\end{tabular}

1 Average annual wages and salaries of equivalent full-time employees using the data for 1947-49 as the base (100.0).

. 2 Population in counties with full-time health departments using 1950 as the base (100.0).

3 See table 2, footnotes 1 and 2.

Sodrce: U. S. Office of Business Economics, Survey of Current Business (National Income Number) 37: 20 (table 27), July 1957, for 1952 through 1956. For earlier years, data were obtained from: U. S. Office of Business Economics, National Income, 1954 Edition, A Supplement to the Survey of Current Business. 
Figure 1. Annual expenditures by local health departments compared with expenditures deflated by wage and salary index and by population increase, 1950-56.

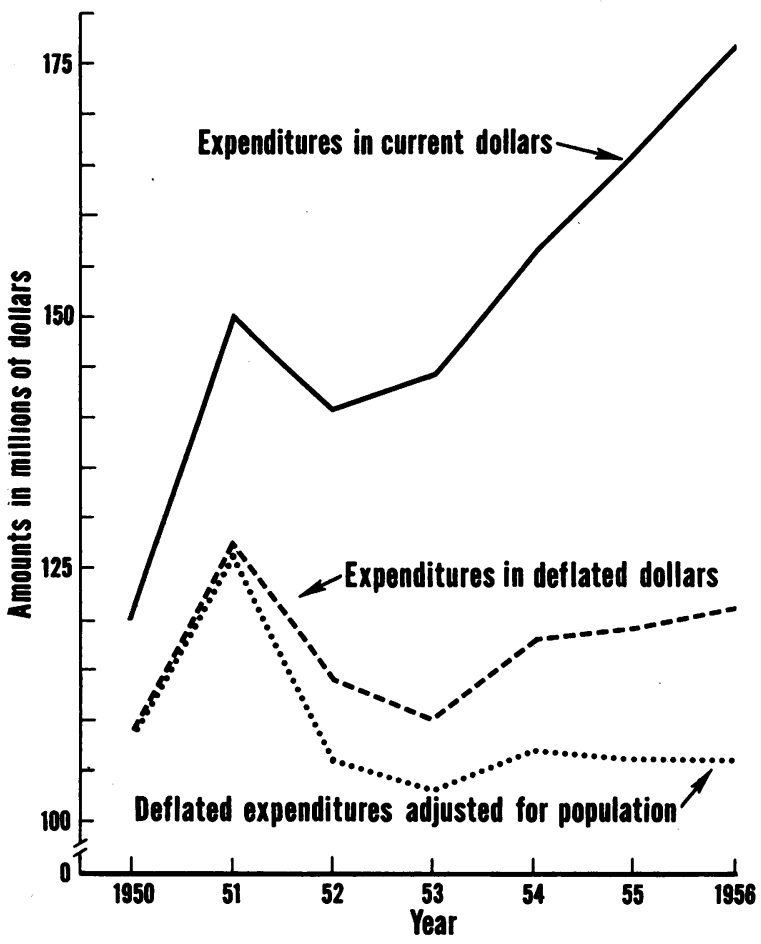

basic data, to relatively large increases in appropriations by four States, New York, Michigan, Ohio, and Pennsylvania. Furthermore,

Table 5. Annual expenditures by local health departments, 1950-56, as percent of gross national product ${ }^{1}$ and index of these percentages, using 1950 as the base

\begin{tabular}{r|r|r}
\hline Year & $\begin{array}{r}\text { Expendi- } \\
\text { tures as per- } \\
\text { cent of gross } \\
\text { national } \\
\text { product }\end{array}$ & $\begin{array}{c}\text { Index of ratio } \\
\text { of expendi- } \\
\text { tures to } \\
\text { gross national } \\
\text { product }\end{array}$ \\
\hline 1950 & 0.422 & 100.0 \\
1951 & .456 & 108.1 \\
1952 & .408 & 96.7 \\
1953 & .397 & 94.1 \\
1955 & .433 & 102.6 \\
\hline 1956 & .424 & 100.5 \\
\hline
\end{tabular}

1 Value of all goods and services produced by the Nation in a given year.

2 See table 2, footnotes 1 and 2.

Source: U. S. Office of Business Economics, Survey of Current Business (National Income Number) 37: 8-9 (table 2), July 1957. the disparity between the expenditures in 1951 and 1952 may not be real, as explained in footnote 2 of table 2. Excluding this one year, however, the maximum increase between the lowest and the highest year is only 10 percent. Local funds parallel the total closely since they constitute the largest component. The State funds follow an even less consistent pattern of growth, the highest expenditure occurring in 1954. Federal funds declined progressively until by 1956 they were about half of the amount available in 1950 .

The figures in the lower part of table 4, if one considers the population increase in counties with organized health departments in addition to adjusted dollar values, indicate an actual decline in "real" expenditures between 1950 and 1956. The effect of these two adjustments is depicted also in figure 1.

\section{Percentage of Gross National Product}

The relative growth or decline of interest in a public endeavor can be appraised by the por-

Figure 2. Index of annual expenditures by local health departments as percentage of gross national product, using 1950 as the base, 1950-56.

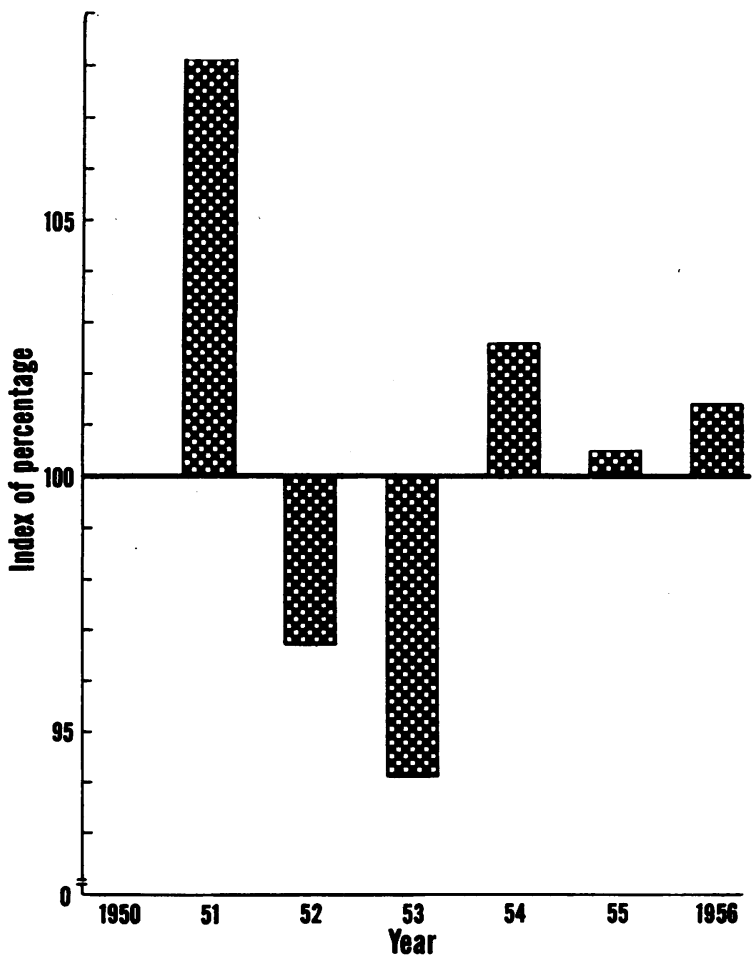


tion of resources that the community diverts to the activity. To obtain such a measure, the monies spent each year by local health departments may be related to the gross national product.

The gross national product is the measurement in terms of current dollar values of all the goods and services produced by the Nation in a given year. What proportion of this total is allocated to public health services provided by local health departments? More specifically, has this proportion increased, decreased, or remained more or less stationary during the years 1950 through 1956 ?

These relationships are shown in table 5 . Expenditures by local health departments between 1950 and 1956 were less than one-half of 1 percent of the gross national product.
The largest increase occurred in 1951, but this apparent increase has already been. somewhat discounted. Other year-to-year variations are well within the estimation errors present in all these data (table 5 and fig. 2). Ignoring the sharp increase in 1951, one is led to conclude that since 1950 there has been no significant increase in expenditures by local health departments.

In considering percentage of gross national product, we need no special adjustment for the increase in population since the gross national product already reflects population changes. Nevertheless, there might be need for additional adjustment for population in terms of the differential increase of the population in areas with full-time health departments compared with the increase of the population for

\section{Table 6. Number of full-time public health workers of different classifications reported by local}

health departments for designated years. ${ }^{1}$

\begin{tabular}{|c|c|c|c|c|c|c|c|c|c|}
\hline Class of personnel & 1957 & 1956 & 1955 & 1954 & 1953 & 1952 & 1951 & 1949 & $\begin{array}{l}\text { Differ- } \\
\text { ence } \\
1957-49\end{array}$ \\
\hline All types.......... & 38,949 & 38,383 & 38,131 & 37,514 & 37,036 & 35,997 & 34,895 & 33,555 & 5,394 \\
\hline Physicians & 1,431 & 1,488 & 1,482 & 1,482 & 1,502 & 1,486 & 1,594 & 1,609 & -178 \\
\hline Public health nurses & 12,956 & 12,900 & 12,783 & 12,574 & 12,492 & 12,045 & 11,843 & 11,251 & 1,705 \\
\hline Clinic nurses & 633 & 581 & 612 & 564 & 621 & 631 & (2) & (2) & $(2)$ \\
\hline Dentists & 281 & 262 & 251 & 236 & 234 & 248 & 233 & 215 & 66 \\
\hline Dental hygienists & 377 & 370 & 375 & 367 & 388 & 384 & $\left({ }^{2}\right)$ & ()$\left.^{2}\right)$ & \\
\hline $\begin{array}{l}\text { Engineers } \\
\text { Professional sanitarians and }\end{array}$ & 367 & 389 & 411 & 396 & 407 & 418 & 407 & 356 & \\
\hline $\begin{array}{l}\text { other sanitation person- } \\
\text { nel }\end{array}$ & 7,315 & 7,063 & 7,151 & 6,932 & 6,810 & 6,638 & 6,461 & 6,531 & 784 \\
\hline Veterinarians & 265 & 295 & 300 & 328 & 327 & 328 & 308 & $(2)$ & $(2)$ \\
\hline Laboratory personnel & 1,290 & 1,286 & 1,302 & 1,325 & 1,301 & 1,315 & 1,385 & 1,391 & -101 \\
\hline Health educators & 259 & 273 & 261 & 276 & 272 & 281 & 256 & 221 & 38 \\
\hline Nutritionists & 102 & 111 & 101 & 101 & 106 & 103 & 102 & 92 & \\
\hline $\begin{array}{l}\text { Medical and psychiatric } \\
\text { social workers }\end{array}$ & 284 & 249 & 222 & 192 & 177 & 200 & 148 & 111 & 173 \\
\hline Psychologists & 59 & 60 & 52 & 41 & $(2)$ & $(2)$ & $(2)$ & $(2)$ & $(2)$ \\
\hline Analysts and statisticians & 183 & 198 & 165 & 168 & 213 & 178 & $(2)$ & (2) & $(2)$ \\
\hline Public health investigators & 329 & 347 & 331 & 388 & 437 & 477 & $(2)$ & $(2)$ & $(2)$ \\
\hline chnicians & 313 & 332 & 327 & 335 & 296 & 308 & $(2)$ & $(2)$ & $(2)$ \\
\hline Physical therapists & 140 & 133 & 118 & 115 & 100 & 73 & $(2)$ & $(2)$ & $(2)$ \\
\hline $\begin{array}{l}\text { Administrative manage- } \\
\text { ment workers }\end{array}$ & 453 & 398 & 356 & 368 & $(2)$ & $(2)$ & $(2)$ & $\left({ }^{(2)}\right.$ & $(2)$ \\
\hline Clerks & 8,645 & 8,472 & 8,477 & 8,288 & 8,280 & 8,022 & 7,520 & 7,184 & 1,461 \\
\hline $\begin{array}{l}\text { Maintenance, } \\
\text { and service }\end{array}$ & 1,837 & 1,849 & 1,814 & 1,784 & 1,911 & 1,769 & 1,847 & $(2)$ & $(2)$ \\
\hline Others & 1,430 & 1,327 & 1,240 & 1,254 & 1,162 & 1,093 & 2,791 & 4,594 & $(3)$ \\
\hline
\end{tabular}

1 District of Columbia personnel and State health district personnel included (adjustment made to eliminate duplication in State personnel serving on State health district staffs). Because of a change in reporting procedures, a count of local personnel was not reported for 1950 .

2 Not reported separately, but included under "Others" except as indicated otherwise.

3 Figure does not represent the true difference since some personnel were included in one group in some years and in another in other years.

Source: As reported to the Public Health Service by local health departments and compiled by State Grants Branch, Division of General Health Services. 
the Nation. This differential increase between 1950 and 1956 was about 3 percent. If the indexes in table 5 were adjusted accordingly, it would indicate that the per capita share of gross national product spent by local public health departments declined slightly between 1950 and 1956.

The general inference that we draw is this: Since 1950 there has been no upward trend in real expenditures by public health departments, and, if the increase of population is taken into consideration, there has been perhaps a slight decline. The decline, nevertheless, may be poignant because it occurred in years of unrivaled economic prosperity and in years when particular segments of our population, children and the aged, who stand to gain most from organized public health efforts, were increasing at an appreciably higher rate than the population at large.

We may examine now, by way of a check, the number and kinds of personnel serving local health departments.

\section{Personnel in Local Health Departments}

The raison d'être of local health departments is to supply directly or otherwise specified health services needed by individuals, families, and the community. The nature and volume of these services may be judged from the number and kinds of personnel employed. Table 6 provides data on full-time personnel for the period 1949 through 1957. Data are not available on the number of part-time personnel employed by local health departments nor on the extent to which these workers have increased or decreased since 1950.

The overall increase of local health department personnel between 1949 and 1957 is 5,394, which is 16 percent, or about 2 percent per year on an average. Since the increase in population in areas served by local health departments during this period has been about the same, one can assume that there has been no per capita increase of service personnel.

An actual decline has occurred in certain types of key personnel in local health departments. Declines in the number of physicians between 1949 and 1957 are observed even without considering the population increase.
Actual declines are observed also in the number of laboratory personnel. Most of the other positions show net gains that are reversed when full-time personnel positions are related to the population increases. One marked exception to this is the small but sharply growing group of medical and psychiatric social workers who more than doubled in number during the interval between 1949 and 1957. The dentists are a second exception. This group is small, but showed an increase of 31 percent between 1949 and 1957.

\section{Summary and Conclusion}

Analysis of three criteria of growth, geognaphic expansion, annual expenditures, and number of full-time health department employees, leads to the conclusion that there has been no growth in local health departments since 1950. In fact, if the population increase in the areas with local health departments is taken into consideration, there is indication of a small decline. This could mean that other agencies are taking over certain needed health services, or that American communities are not so much interested in health, or perhaps health needs that can be dealt with effectively by local health departments have diminished.

Further research is needed to ascertain which of these factors, or in what combinations these or perhaps still other factors, may account for the apparent lack of growth in local health departments. Even more fundamental research is required into methods of reexamining our objectives and determining priorities for local health departments to keep in tune with the times in a rapidly changing society. Also, more precise and objective methods of measuring accomplishment need to be devised in order to learn how best to apportion available funds for local health services in different communities with varying needs and resources.

\section{REFERENCES}

(1) A critique of community public health services. Am. J. Pub. Health 47:1-48, November (pt. 2) 1957.

(2) Knutson, J. W. : Ferment in public health. Am. J. Pub. Health 47 : 1487-1492, December 1957.

(3) U. S. Public Health Service: The development of community health services. Material prepared 
for the 1958 Annual Meeting of the National Advisory Committee on Local Health Departments, March 18, 1958. Washington, D. C., 1958, pp. 1-16. Mimeographed.

(4) Williams, R. C.: The United States Public Health Service, 1798-1950. Washington, D. C., Commissioned Officers Association, 1950, p. 142.

(5) Ferrell, J. A., Smillie, W. G., Covington, P. W., and Mead, P. A. : Health departments of States and Provinces of the United States and Canada. Pub. Health Bull. No. 184 (Revised). Washington, D. C., U. S. Government Printing Office, 1932, pp. 43-44.

(6) Emerson, H.: Local health units for the Nation.
New York, N. Y., Commonwealth Fund, 1945, p. 14.

(7) U. S. Public Health Service: Salaries of local public health workers, August 1954. PHS Pub. No. 425. Washington, D. C., U. S. Government Printing Office, 1955.

(8) National income and product of the United States, 1956. Basic data on the national economy [for 1952 through 1956]. Survey of Current Business (National Income Number) 37: 4-40 (16 and 19), July 1957. For earlier years see National Income; A Supplement to the Survey of Current Business (1954).

\section{Medical Education Group Formed}

The Surgeon General's Consultant Group on Medical Education, composed of 21 members, held its first meeting in Washington, D. C., December 8, 1958, with Frank Bane, former executive secretary of the Council of State Governments, as chairman.

The members of the group, national leaders in medicine, education, and public affairs, were invited by Dr. Leroy E. Burney, Surgeon General of the Public Health Service, to seek answers to the question: How can the Nation be supplied with adequate numbers of wellqualified physicians over the next decade?

Dr. Burney pointed out that the present medical school output will not keep pace with the economic and population growth of the United States, and that the present ratio of 132 physicians to every 100,000 persons will be difficult to maintain. He said that twice as many interns are needed. Public health organizations are short about 10,000 physicians, and 6,000 more psychiatrists are required to fill present vacancies. Dr. Burney also said that people are visiting their doctors twice as often as they were 25 or 30 years ago and are using hospitals at a rate three times that of
1940. With half the population in 1970 expected to be under 20 and over 65 years of age, Dr. Burney observed that health needs will change, particularly with regard to chronic diseases.

Dr. Burney has suggested that the Consultant Group on Medical Education might approach the question of supplying the Nation with adequate numbers of physicians in the following manner:

1. Appraise existing data, plans, and proposals related to medical schools and the $\mathrm{Na}$ tion's need for physicians.

2. Identify matters upon which agreement has been reached and those that require further study.

3. Recommend actions which might be taken to achieve reasonable and acceptable goals within the next 10 to 20 years.

4. Recommend any specific actions which educational institutions, foundations, industry, and local, State, and Federal governments should take in meeting these goals.

5. Recommend the proper role, if any, that the Public Health Service should play and the steps it should take. 